$2(2)(2021) 46-50$
Indonesian Journal of
Health Community
http://e-journal.ivet.ac.id/index.php/ijheco

\title{
Faktor yang Berhubungan dengan Kadar Hemoglobin Pada Petani Bawang Merah
}

\author{
Devi Ayu Susilowati ${ }^{1}$, Siti Muzayanah ${ }^{1}$ \\ ${ }^{1}$ Politeknik Mitra Karya Mandiri, Politeknik Mitra Karya Mandiri
}

\begin{tabular}{l} 
Info Articles \\
\hline Sejarah Artikel: \\
Disubmit 19 Agustuss 2021 \\
Direvisi 4 September 2021 \\
Disetujui 12 Oktober 2021 \\
\hline Keywords: \\
Farmer spraying; pesticides,; \\
hemoglobin levels.
\end{tabular}

\begin{abstract}
Abstrak
Kegiatan di sektor pertanian tidak terlepas dari penggunaan pestisida untuk menghindari hasil pertanian dari hama. Penggunaan pestisida yang berisiko dapat menimbulkan gangguan abnormalitas pada profil darah. Penelitian ini bertujuan untuk mengetahui faktor-faktor yang berhubungan dengan kadar hemoglobin pada petani bawang merah di Desa Tegalglagah Kabupaten Brebes. Penelitian ini menggunakan desain cross sectional. Pengambilan sampel dengan total sampling sebanyak 42 orang, pengambilan sampel darah vena untuk mengetahui kadar hemoglobn responden menggunakan metode Cyanmethemoglobin. Hasil peneltian menunjukkan sebagian besar kadar hemoglobin responden yang terpapar pestisida adalah normal $(52.38 \%)$, sebagian besar responden merokok ketika sedang menyemprot pestisida $(73,80 \%)$, sebagian besar menggunakan Alat Pelindung Diri (APD) ketika sedang menyemprot (52,38\%), serta sebagian besar melakukan kegiatan menyemprot <4 jam per harinya $(59,52 \%)$, faktor yang berhubungan dengan kadar hemoglobin adalah penggunaan APD ketika menyemprot dengan $p$ value 0,013 dan lama kerja per hari dengan p-value 0,032. Disimpulkan bahwa penggunaan APD ketika menyemprot dan lama kerja per hari berhubungan dengan kadar hemoglobin.

Kata Kunci: Petani penyemprot, pestisida, Kadar hemoglobin
\end{abstract}

\section{Abstract}

Activities in the agricultural sector cannot be separated from the use of pesticides to prevent agricultural products from pests. The use of pesticides that are at risk can cause abnormalities in the blood profile. This study aims to determine the factors associated with hemoglobin levels in farmers exposed to pesticides in Tegalglagah Village, Brebes Regency. This study used a cross sectional design. Sampling with a total sampling of 42 people, venous blood sampling to determine the hemoglobn level of respondents using the Cyanmethemoglobin method. The results showed that most of the respondents who were exposed to pesticides were normal (52.38\%), most of the respondents smoked while spraying pesticides (73.80\%), most of them used Personal Protective Equipment (PPE) while spraying (52.38\%)), and most of them sprayed $<4$ hours per day (59.52\%), the factors related to hemoglobin levels were the use of PPE when spraying with a p-value of 0.013 and length of work per day with a p-value of 0.032. It was concluded that the use of PPE when spraying and the length of work per day were related to hemoglobin levels.

Keywords: Farmer spraying, pesticides, hemoglobin levels.

\footnotetext{
Alamat Korespondensi:

E-mail: deviayuwais@gmail.com
}

p-ISSN 2721-8503 


\section{PENDAHULUAN}

Indonesia adalah salah satu negara berkembang sekaligus juga termasuk negara agraris oleh sebab itu sebagian besar penduduknyamemili mata pencaharian sebagai petani. Sektor pertanian adalah salah satu dari tiga bidang di sektor rill Indonesia yang memiliki kontribusi paling besar terhadap Produk Domestik Bruto (PDB) sehingga sektor ini mampu menopang perekonomian nasional. Hal ini terlihat dari kontribusi sektor pertanian terhadap PDB Indonesia mencapai 12,84\%.(Fikri,2012). Kegiatan di sektor pertanian tidak terlepas dari penggunaan pestisida untuk menghindari hasil pertanian dari hama. The Food and Agriculture Organization of the United Nations mendefinisikan pestisida adalah zat atau campuran zat kimia atau biologi yang digunakan untuk mencegah, mengontrol hama dan hewan-hewan yang menyebabkan kerusakan atau mengganggu produksi serta mengontrol pertumbuhan tanaman.(FAO,2014) Kegiatan petani yang bersinggungan dengan pestisida jika tidak dilakukan dengan aman maka akan menimbulkan efek kesehatan bagi penggunanya diantaranya adalah dapat menjadi zat mutagenik, karsinogenik, pengganggu endokrin, pengganggu sistem reproduksi dan zat neurotoksik di dalam tubuh.(Sanborn,2007)

Terpaparnya tubuh oleh pestisida berdampak pada komponen yang ada dalam tubuh manusia, salah satunya adalah darah. Pestisida dapat menimbulkan abnormalitas pada profil darah karena pestisida dapat mengganggu organ-organ pembentuk sel-sel darah, proses pembentukan sel-sel darah dan juga sistem imunitas tubuh.(Kiswari,2014) Sel darah terbanyak yang ada dalam tubuh adalah sel darah merah. Sel darah merah mempunyai protein utamanya yaitu hemoglobin. Hemoglobin adalah komponen utama dari sel darah merah (eritrosit), merupakan protein konjugasi yang berfungsi untuk transportasi oksigen $\left(\mathrm{O}_{2}\right) .(\mathrm{Djau}, 2010)$

Penelitian pada petani hortikultura di Desa Gombong Kecamatan Belik Kabupaten Pemalang tahun 2013 didapatkan 19 petani (47,5\%) mengalami keracunan akibat pestisida dan 17 petani (42,5\%) menderita anemia. Kejadian keracunan akibat pestisida dan anemia pada petani di Desa Gombong dapat dipengaruhi oleh banyak faktor, baik lingkungan maupun perilaku petani itu sendiri. (Yuliana,2017) Anemia merupakan keadaan masa eritrosit atau hemoglobin yang beredar tidak memenuhi fungsinya untuk menyediakan oksigen bagi jaringan tubuh. Secara laboratoris, anemia dijabarkan sebagai penurunan kadar hemoglobin serta hitung eritrosit dan hematokrit di bawah normal. Pada pekerja, anemia akan berdampak pada penurunan produktivitas kerja.(Norsita,2018)

Reddy P.B dan Jagdish Kanojia melakukan penelitian pada petani yang terpapar pestisida di beberapa desa di India menyimpulkan hal yang sama yaitu terdapat penurunan kadar serum kolinesterase dan parameter hematologi seperti Hemoglobin, Hct dan RBC.(Yuliana,2017) Keracunan kronis akibat terpapar pestisida dapat berbentuk abnormalitas pada profil darah seperti hemoglobin, netrofil dan leukosit, kerusakan hormon endokrin, sistem syaraf, dan sistem pencernaan, toksisitas kronik mengacu pada paparan yang berulang mengalami akumulasi dalam sistem biologi yang sulit terdegradasi dalam lingkungan.(Reddy,2012)

Berdasarkan penjelasan dan uraian tersebut, peneliti tertarik untuk meneliti lebih lanjut mengenai faktor-faktor yang berhubungan dengan kadar hemoglobin pada petani bawang merah di Desa Tegalglagah Kabupaten Brebes yang bertujuan membuktikan faktor lama kerja, merokok dan kelengkapan APD yang digunakan saat menyemprot berhubungan dengan kadar hemoglobin pada petani bawang merah.

\section{METODE}

Jenis penelitian observasional analitik dengan metode cross sectional. Penelitian ini dilakukan di Desa Tegalglagah RT 5 RW 11 Kecamatan Bulakamba Kabupaten Brebes. Penentuan jumlah sampel dalam penelitian ini dengan menggunakan total sampling sejumlah 43 sampel.

Variabel dependen dalam penelitian ini adalah kadar hemoglobin yang didapat dari sampel darah vena petani bawang merah sebanyak 3 cc dengan metode Cyanmethemoglobin yang diperiksa di Laboratorium Politeknik Mitra Karya Mandiri. Variabel independen yang diteliti adalah merokok ketika menyemprot, lama menyemprot per hari dalam satu minggu, dan kelengkapan Alat Pelindung Diri (APD) ketika menyemprot. Pengumpulan data primer dilakukan dengan wawancara menggunakan kuesioner yang sebelumnya sampel telah diberikan informed concent. Hasil penelitian dianalisis secara bivariat menggunakan yaitu chi square menggunakan alat bantu program komputer aplikasi statistical product and service solutions (SPSS) dengan tingkat kemaknaan $\mathrm{p}<0,05$.

\section{HASIL DAN PEMBAHASAN}

Penelitian dilakukan di Desa Tegalglagah Kabupaten Brebes pada 42 petani penyemprot pestisida. Hasil pemeriksaan kadar hemoglobin diperoleh responden memiliki kadar hemoglobin yang 
normal (52.38\%). Sebagian besar responden merokok ketika sedang menyemprot pestisida $(73,80 \%)$, sebagian besar responden menggunakan Alat Pelindung Diri (APD) ketika sedang menyemprot $(52,38 \%)$, sebagian besar melakukan kegiatan menyemprot $<4$ jam per harinya $(59,52 \%)$, ditunjukkan pada Tabel 1.

Tabel 1. Karakteristik Responden

\begin{tabular}{clcc}
\hline No & \multicolumn{1}{c}{ Karakteristik } & F & \% \\
\hline 1. & Merokok ketika menyemprot & & \\
& Ya & 31 & 37,81 \\
& Tidak & 11 & 26,19 \\
2. & Penggunaan APD & & \\
& Tidak & 22 & 52,38 \\
$\quad$ Ya & 20 & 47,62 \\
3. $\quad$ Lama kerja per hari & 17 & 40,47 \\
& >4 jam/hari & 25 & 59,53 \\
\hline
\end{tabular}

Hasil analisis bivariat dengan uji chi-square diketahui bahwa faktor yang berhubungan dengan kadar hemoglobin pada petani bawang merah adalah kelengkapan penggunaan APD ketika menyemprot $(p$ value 0,013$)$ dan lama menyemprot dalam sehari $(p$ value 0,032$)$ ditunjukan pada Tabel 2.

Tabel 2. Hubungan Merokok ketika Menyemprot, Penggunaan APD ketika Menyemprot dan Lama Menyemprot dalam Sehari pada Petani Bawang Merah di Desa Tegalglagah Kabupaten Brebes

\begin{tabular}{|c|c|c|c|c|c|c|c|}
\hline \multirow{3}{*}{ Variabel } & \multicolumn{4}{|c|}{ Kadar hemoglobin } & \multirow{2}{*}{\multicolumn{2}{|c|}{ Total }} & \multirow{3}{*}{$p$-value } \\
\hline & \multicolumn{2}{|c|}{ Abnormal } & \multicolumn{2}{|c|}{ Normal } & & & \\
\hline & $\mathrm{n}$ & $\%$ & $\mathrm{n}$ & $\%$ & $\mathrm{n}$ & $\%$ & \\
\hline \multicolumn{8}{|c|}{ Merokok ketika menyemprot } \\
\hline $\mathrm{Ya}$ & 13 & 41,9 & 18 & 58,1 & 31 & 100,0 & \multirow[t]{2}{*}{0,375} \\
\hline Tidak & 7 & 63,6 & 4 & 36,4 & 11 & 100,0 & \\
\hline \multicolumn{8}{|c|}{ Penggunaan APD } \\
\hline Tidak & 15 & 25,0 & 7 & 31,8 & 22 & 100,0 & \multirow[t]{2}{*}{0,013} \\
\hline Ya & 5 & 25,0 & 15 & 75,0 & 20 & 100,0 & \\
\hline \multicolumn{8}{|c|}{ Lama kerja per hari } \\
\hline$\geq 4 \mathrm{jam} / \mathrm{hari}$ & 12 & 70,6 & 5 & 29,4 & 17 & 100,0 & \multirow[t]{2}{*}{0,032} \\
\hline$<4 \mathrm{jam} / \mathrm{hari}$ & 8 & 32,0 & 17 & 68 & 25 & 100,0 & \\
\hline
\end{tabular}

Hasil penelitian menunjukkan bahwa responden yang merokok ketika menyemprot lebih banyak dibandingkan dengan responden yang tidak merokok ketika menyemprot yaitu sebesar $73,8 \%$, dengan nilai $\mathrm{p}$ value sebesar 0,375 yang artinya tidak ada hubungan antara merokok ketika menyemprot dengan kadar hemoglobin pada petani bawang merah di Desa Tegalglagah Kabupaten Brebes. Kebiasaan merokok saat melakukan aplikasi pestisida secara tidak sengaja dapat menyebabkan masuknya pestisida melalui hisapan rokok. Merokok merupakan salah satu faktor penting yang mempengaruhi kadar hemoglobin, karena merokok dapat menyebabkan rusaknya sel silia pada saluran pernapasan sehingga kerusakan pada paru dapat mengakibatkan semakin banyak jumlah zat kimia yang tedapat dalam rokok seperti logam berat masuk kedalam tubuh sehingga berpengaruh pula pada penurunankadar hemoglobin dalam darah. ada karbon monoksida yang bersifat toksik yang bertentangan dengan oksigen, ketika kadar CO dalam darah meningkat, kemampuan tubuh untuk membawa oksigen secara signifikan menurun.(Adiwijayanti,2015)

Berdasarkan hasil penelitian diperoleh responden yang menggunakan Alat Pelindung Diri (APD) ketika menyemprot lebih banyak dibandingkan dengan responden yang tidak menggunakan APD ketika sedang menyemprot yaitu sebesar $52,3 \%$, dengan $p$ value sebesar 0,013 yang artinya ada hubungan antara penggunaan APD ketika menyemprot dengan kadar hemoglobin pada petani bawang merah di Desa Tegalglagah Kabupaten Brebes. Namun masih ada juga responden yang tidak menggunakan APD bahkan sampai tidak memakai baju dengan alasan panas matahari dan kegerahan sehingga responden tidak menggunakan APD secara lengkap. APD wajib digunakan oleh petani yang 
akan kontak dengan pestisida untuk mengurangi masuknya pestisida baik melalui jalur pernapasan, inhalasi, kulit, mata dan mulut, APD yang digunakan adalah masker untuk menutupi hidung dan mulut, topi, sarung tangan, baju lengan panjang dan celana panjang.(Arisa,2017) Penelitian ini sejalan dengan penelitian yang dilakukan oleh Maksuk dkk yang memperoleh hasil bahwa penggunaan APD berhubungan dengan kadar hemoglobin pada pekerja penyemprot gulma dengan p-value 0,009. (Maksus,2019) Penggunaan APD pada saat menyemprot sangat berpengaruh terhadap banyaknya pestisida yang masuk ke dalam tubuh petani. Penggunaan APD harus sesuai prosedur menurut Litbang Pertanian. (Litbang,2014) Hasil penelitian lainnya juga menunjukkan bahwa terdapat hubungan yang signifikan antara penggunaan APD yang tidak baik dengan kejadian anemia $(p$-value $=0,025)$ (Imelda,2020)

Berdasarkan hasil penelitian diperoleh responden yang menyemprot $<4$ jam per hari lebih banyak dibandingkan dengan responden yang menyemprot $\geq 4$ jam/hari yaitu sebesar $59,5 \%$, dengan nilai $p$-value sebesar 0,032 yang artinya ada hubungan lama menyemprot per hari dengan kadar hemoglobin pada petani bawang merah di Desa Tegalglagah Kabupaten Brebes. Lama kerja ketika menyemprot merupakan waktu yang diperlukan responden untuk melakukan aktivitas pekerjaan yaitu menyemprot dalam sehari. Semakin lama seseorang bekerja, maka semakin sering juga pekerja tersebut kontak dengan bahan aktif pestisida sehingga mengakibatkan bahan aktif dalam pestisida dapat masuk kedalam tubuh dan terkumulasi. Penelitian yang dilakukan oleh Maksus dkk memperoleh hasil pekerja yang berkerja $\geq 7 \mathrm{jam} /$ hari lebih banyak yang mengalami anemia, tetapi secara statistik tidak ada hubungan antara lama kerja dengan anemia $(p$-value $=0,251)$. (Maksuk,2017) Penelitian lain juga memperoleh hasil tidak ada hubungan antara lama kontak dengan kejadian keracunan pestisida ( $p$ value $=0,166)$. (Rihardini,2016)

\section{SIMPULAN}

Berdasarkan hasil analisis penelitian yang dilakukan maka dapat disimpulkan bahwa petani bawang merah yang memiliki kadar hemoglobin normal lebih banyak dengan petani bawang merah yang memiliki kadar hemoglobin abnormal. Faktor yang berhubungan dengan kadar hemoglobin pada petani bawang merah adalah kelengkapan APD ketika menyemprot dan lama kerja dalam menyemprot per hari, sedangkan faktor yang tidak berhubungan dengan kadar hemoglobin pada petani yang bawang merah adalah merokok ketika sedang menyemprot.

\section{DAFTAR PUSTAKA}

Adiwijayanti, B. R. 2015. Hubungan Karakteristik Individu Terhadap Kadar Timbal Dalam Darah Dan Dampaknya Pada Kadar Hemoglobin Pekerja Percetakan Di Kawasan Megamall Ciputat Tahun 2015. Universitas Islam Negeri Syarif Hidayatullah.

Arisa, Arrasyid, A. S. 2017. Pemeriksaan Kadar Pestisida Dalam Darah Petani Bawang Merah Di Nagari Alahan Panjang. J. Sainstek Vol. 9, 14-18.

Djau R. 2010. Faktor risiko kejadian Anemia dan keracunan pestisida pada pekerja penyemprot gulma di kebun kelapa sawit PT.Agro Indomas Kab. Seruyan Kalimantan Tengah. Universitas Diponegoro.

FAO. 2014. The International Code of Conduct on Pesticide Management. Roma. WHO.

Fikri E, Setiani O, N. 2012. Hubungan paparan pestisida dengan kandungan arsen dalam urin dan kejadian Anemia. Jurnal Kesehatan Lingkungan Indonesia. 11, 29-37.

Imelda Yuristi, Nurmaini Nurmaini, A. S. 2020. Relationship between Spraying Technique and Use of PPE (Personal Protective Equipment) With Anemia Farmers in Juhar Ginting Sadanioga Village, Karo Regency in 2018. Britain Int. Exact Sci. J. Vol. 2.

Kiswari. 2014. Hematologi dan Transfusi. Erlangga, Jakarta.

Litbang Pertanian. 2014. Teknik Penyemprotan Pestisida. Pusat Penelitian Dan Pengembangan Hortikultura. 
Maksuk, Andani, P. \& Suzanna, Amin, M. 2017. Analisis Faktor Risiko Kejadian Anemia Pada Aplikator Herbisida (Studi Kasus Di Perkebunan Kelapa Sawit Pt. S Kabupaten Banyuasin). J. Ilmu Kesehat. Masy. Vol 8, 34-42.

Maksus, Dian Pratiwi, Maliha Amin, S. 2019. Kadar Hemoglobin Pekerja Penyemprot Gulma Akibat Paparan Pestisida DI Perkebunan Kelapa Sawit. J. Kesehat. Poltekkes Palembang Vol. 14, 45-52.

Norsita Agustina, N. 2018. Paparan Pestisida Terhadap Kejadian Anemia Pada Petani Hortikultura.. Universitas Islam Kalimantan.

Reddy PB, J. K. 2012. Clinico pathological effects of pesticides exposure on farm workers. DAV Int. J. Sci. Vol $1,119-121$

Rihardini Okvitasari, Choiroel Anwa, S. 2016. Hubungan Antara Keracunan Pestisida Dengan Kejadian Anemia Pada Petani Kentang Di Gabungan Kelompok Tani Al-Farruq Desa Patak Banteng Kecamatan Kejajar Kabupaten Wonosobo Tahun 2016. Jurnal Kesehatan Lingkungan

Sanborn M, Kerr KJ, Sanin LH, Cole DC, Bassil KL, V. C. 2007. Non-cancer health effects of pesticides Systematic review and implications for family doctors. Can Fam Physician. Vol. 53. $1712-1720$.

Yuliana Prasetya Ningningsih, Desto Arisandi, dan P. D. R. S. 2017. Presentase Kejadian Anemia pada Petani Terpapar Pestisida di Kelompok Tani Karang Rejo, Dusun Krinjing Lor, Desa Jatisarono, Kecamatan Nanggulan, Kabupaten Kulon Progo. Yogyakarta. Stikes Guna Bangsa. 